\title{
Strength and microstructural behaviour of concrete incorporating laterite sand in binary blended cement
}

\author{
Rajapriya Raja (Main and Corresponding Author) \\ Department of Civil Engineering, College of Engineering - Guindy, Anna University \\ Chennai - 600 025, Tamil Nadu (India) \\ rajapriya.civil@gmail.com \\ https://orcid.org/0000-0003-3341-2143
}

\section{Ponmalar Vijayan}

Department of Civil Engineering, College of Engineering - Guindy, Anna University

Chennai - 600 025, Tamil Nadu (India)

ponmalar_v@annauniv.edu

https://orcid.org/0000-0002-6289-9475

Manuscript Code: 14054

Date of Acceptance/Reception: 02.11.20/20.10.19

DOI: DOI: 10.7764/RDLC.19.3.422

\begin{abstract}
This paper explores the performance of concrete using laterite sand as a fine aggregate alternative by replacing manufactured sand ( $\mathrm{M}$-sand, produced from hard granite stones by crushing) at $25 \%$ intervals ranging from $0 \%$ to $100 \%$. Preliminary tests were conducted to ascertain the properties of $\mathrm{M}$ sand and laterite sand that meet the recommended standards for natural aggregates. M30 grade concrete mixtures were produced, and the specimens were cured for 7 and 28 days. The slump test was carried out to assess the workability as per Indian Standards. Furthermore, the concrete specimens were prepared in the form of cubes, cylinders, and beams to assess the mechanical performance. Also, control and optimum mixtures were chosen to understand its morphological characteristics by conducting Scanning Electron Microscopy (SEM), Energy Dispersive X-ray Spectroscopy (EDS), X-Ray Diffraction (XRD) and Thermogravimetric Analysis (TGA). Results showed that higher laterite content led to less workable concrete, and $25 \%$ replacement of laterite sand improved by about $12 \%, 11 \%$ and $13 \%$ respectively compressive, split-tensile, and flexure strengths. Based on the SEM analysis, the optimum mixture showed a more compact microstructure. The EDS analysis confirmed the presence of various hydration products, while the XRD analysis indicated that the L25 samples had additional peaks of tobermorite and xonotlite. The results of TGA are also in agreement with the assertion.
\end{abstract}

Keywords: Laterite sand, M-Sand, strength, microstructure, thermogravimetric analysis.

River sand has become a non-renewable material that has led researchers to focus on finding the use of alternative materials for fine aggregate. Utilization of the waste materials as an alternative to fine aggregates in construction decreases the required amount of sand, which in turn reduces environmental pollution and conserves natural resources (Awoyera, Dawson, Thom, \& Akinmusuru, 2017). Tremendous attempts have been made to replace river sand with $M$ sand, although the use of $\mathrm{M}$-sand has met the demand for fine aggregates at a stable price, it has unfortunately not been a better alternative by creating some environmental consequences such as noise and dust pollution, drastic fall in the groundwater table, etc. due to quarrying (Rajan, \& Joy, 2016).

Laterite, due to its large availability and low cost, is considered as a building material in the tropical and subtropical regions of the world (Adepegba, 1975; Lasisi, Ajayi, \& Osunade, 1984). Balogun and Adepegba (1982) recommended that laterite with a clay content of less than $40 \%$ may be used in concrete, whereas laterite with a high clay content may end up in low compressive strength and suggested that it is very important to explain how similar the laterized concrete properties are related to the normal concrete properties. In many of the research works (Alawode, \& Idowu, 2011; Lasisi, \& Osunade, 1985; Lasisi, Osunade, \& Adewale, 1990; Olawuyi, \& Olusola, 2010; and Ukpata, \& Ephraim, 2012), the workability of concrete containing laterite as a fine aggregate decrease with an increase in the laterite replacement level. i.e., only true slump occurred. According to the findings of Udoeyo et al. (2010), an increase in laterite content has led to the introduction of more laterite clay fines into the mixture, resulting in an increase in the specific surface area of aggregates, which has subsequently resulted in the reduction in the workability of the mixtures. Udoeyo, Iron, \& Odim, (2006) concluded that the compressive strength value decreases with increasing the replacement level of the river sand by laterite and can be used as a partial replacement for the fine aggregate up to a level of $40 \%$ that can provide the intended strength. Awoyera et al. (2017) stated that the interfacial bonding between the constituent 
materials and the size of the pores are the major contributor to the strength of concrete by conducting microstructural studies on laterized concrete. Currently, the use of waste materials for the replacement of construction materials is becoming noticeable areas of research (Sateshkumar, et al. 2018). To reduce carbon dioxide emissions during cement production, cement can be partially replaced by various by-products such as fly ash, ground granulated blast furnace slag, micro silica, etc (Nandhini, \& Ponmalar, 2018).

The above-mentioned studies focused mainly on concrete behaviour with varying levels of laterite soil substitution for river sand. There has not yet been a detailed investigation of the behaviour of concrete with the combination of M-sand and laterite sand and the implications of supplementary cementitious materials such as Fly Ash, GGBFS, and Silica Fume on laterized concrete. The aim of this study is therefore to produce concrete incorporating fly ash, where the fine aggregate is replaced by different proportions of manufactured sand and laterite sand and to determine the strength performance and microstructural behaviour.

Methodology

\section{Materials and Material Characterization}

The binders used in this study are cement and fly ash. Cement used in this study is a 53 grade Ultratech Ordinary Portland Cement (OPC) purchased from a local supplier confirming with Indian standard (IS 12269, 2013). Fly ash ensuring with the standard specified in IS 3812 (2003), Part 2 is the supplementary cementitious material used here. It was obtained from the Ennore thermal power plant, India. The chemical composition of binders is given in Table 1. Crushed aggregates of granite stones obtained from the nearby supplier are used, was of maximum size $20 \mathrm{~mm}$. M-sand was procured from a local supplier and laterite scraps were obtained from a locality of Calicut, Kerala. The laterite scraps were crushed and sieved through $4.75 \mathrm{~mm}$ sieve which is shown in Figure 1. The investigation of the engineering properties of the aggregates and the results comply with IS 2386-2016 (Part 3 \& 4) are listed in Table 2. The combined sieve analysis of fine aggregates is shown in Figure 2. The superplasticizer used here is Auramix 400, a polycarboxylic ether (PCE). It is obtained from FORSOC chemicals, India. This is high performance superplasticizer intended for high water reduction and long workability retention.

Figure 1. Laterite. Source: Self-Elaboration.

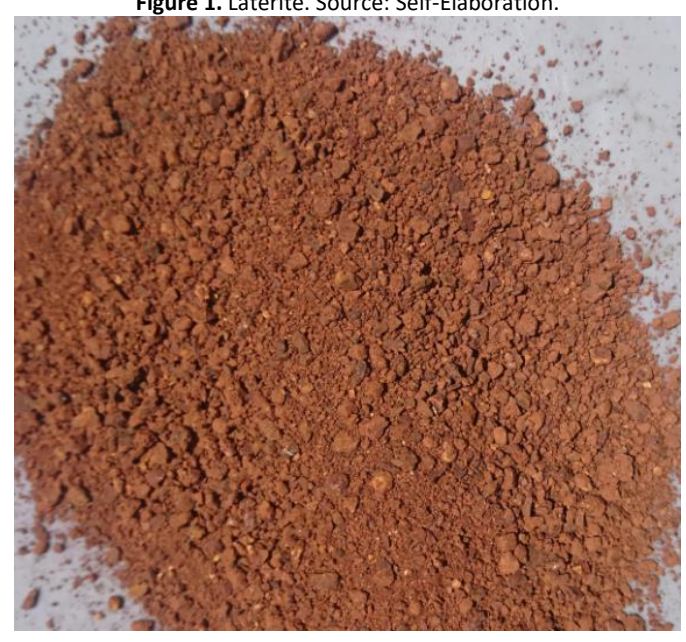

Table 1. Chemical composition of binders. Source: Self-Elaboration.

\begin{tabular}{ccccccccccc}
\hline Oxides (\%) & $\mathrm{CaO}$ & $\mathrm{SiO}_{2}$ & $\mathrm{Al}_{2} \mathrm{O}_{3}$ & $\mathrm{Fe}_{2} \mathrm{O}_{3}$ & $\mathrm{SO}_{3}$ & $\mathrm{MgO}$ & $\mathrm{K}_{2} \mathrm{O}$ & $\mathrm{Na}_{2} \mathrm{O}$ & LOI & Others \\
\hline Cement & 64.2 & 19.4 & 6.1 & 2.1 & 1.8 & 1.3 & 0.3 & 0.2 & 2.8 & 1.8 \\
Fly Ash & 3.6 & 46.3 & 24.8 & 10.2 & 2.3 & 1.6 & 0.6 & 0.5 & 1.7 & 8.4 \\
\hline
\end{tabular}




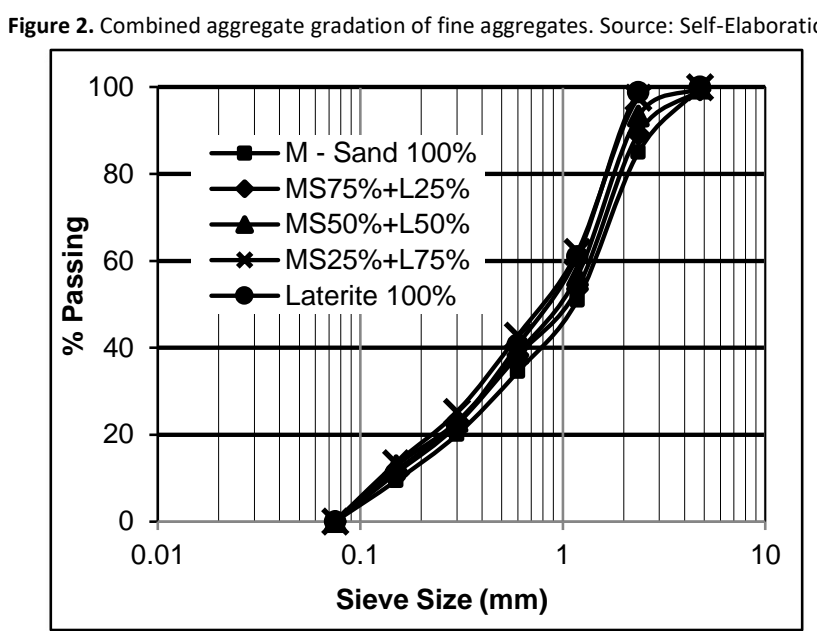

Table 2. Physical properties of fine aggregates. Source: Self-Elaboration.

\begin{tabular}{lccc}
\hline Physical Properties & M - Sand & Laterite & Coarse Aggregate \\
\hline Fineness Modulus & 3.01 & 2.96 & 3.72 \\
Bulk density $\left(\mathrm{kg} / \mathrm{m}^{3}\right)$ & 1768 & 1945 & 1650 \\
Specific gravity & 2.53 & 2.81 & 2.64 \\
Water Absorption (\%) & 2.0 & 2.5 & 1 \\
\hline
\end{tabular}

Table 3. Mix proportion design for concrete samples. Source: Self-Elaboration.

\begin{tabular}{cccccccc}
\hline Mix & $\begin{array}{c}\text { Cement } \\
\left(\mathrm{kg} / \mathrm{m}^{3}\right)\end{array}$ & $\begin{array}{c}\text { Fly Ash } \\
\left(\mathrm{kg} / \mathrm{m}^{3}\right)\end{array}$ & $\begin{array}{c}\text { M-Sand } \\
\left(\mathrm{kg} / \mathrm{m}^{3}\right)\end{array}$ & $\begin{array}{c}\text { Laterite } \\
\left(\mathrm{kg} / \mathrm{m}^{3}\right)\end{array}$ & $\begin{array}{c}\text { Coarse } \\
\text { aggregate } \\
\left(\mathrm{kg} / \mathrm{m}^{3}\right)\end{array}$ & $\begin{array}{c}\text { Water } \\
\left(\mathrm{kg} / \mathrm{m}^{3}\right)\end{array}$ & $\begin{array}{c}\text { SP } \\
\left(\mathrm{kg} / \mathrm{m}^{3}\right)\end{array}$ \\
\hline L0 & 280 & 70 & 700 & - & 1191 & 160 & 1.4 \\
L25 & 280 & 70 & 532.5 & 177.5 & 1191 & 160 & 1.4 \\
L50 & 280 & 70 & 365 & 365 & 1191 & 160 & 1.4 \\
L75 & 280 & 70 & 187.5 & 562.5 & 1191 & 160 & 1.4 \\
L100 & 280 & 70 & - & 760 & 1191 & 160 & 1.4 \\
\hline
\end{tabular}

\section{Mix Design}

Concrete mixes are performed for the proportioned laterized concrete samples, based on the mix proportion design as per IS 10262 (2019) shown in Table 3. Characteristic compressive strength of $30 \mathrm{MPa}$ was targeted. Batches of concrete containing $0,25,50,75$, and $100 \%$ of laterite by weight of $\mathrm{M}$-sand and are used as replacements while mixing was done mechanically using tilting mixer. Totally five mixes were designed. The mixes without laterite replacements are taken as reference. A constant w/c ratio of 0.5 and a superplasticizer dosage of $0.4 \%$ is used throughout the mixes. The quantity of fly ash used in the mixes is $20 \%$ of the total cementitious composition.

\section{Experimentation}

Workability. Workability was evaluated using the slump cone apparatus as per Indian Standards IS 7320 (2018). It is an empirical method for assessing the consistency or fluidity of the fresh mix. This is an indication of how much water was used to obtain the proper mix. The measurement of the slump was the difference between the height of the mold and the concrete height after the removal of the mold.

Compressive Strength. The specimens used for this test were of the size of the concrete cubes of $150 \times 150 \times 150 \mathrm{~mm}$. The cubes were manufactured in triplets and cured for 7 and 28 days in water. This experiment was carried out using a compression testing machine with a load capacity of $2000 \mathrm{kN}$. The incremental loading continued until the specimens failed and the compressive strength value was taken as the ratio of load at the failure to the cross-sectional area of the specimens. 
Split-tensile and Flexural Strength. These two tests are an indirect measure of the tensile strength. In which the splittensile strength is the measurement of the ability of the cylindrical specimens to resist tensile stress by applying the compressive load on its horizontal axis, while the flexural strength is the ability of the concrete beam to withstand bending stress. The concrete samples were prepared as $150 \times 300 \mathrm{~mm}$ (diameter $\times$ height) dimension cylinders for splitting tensile testing, and $100 \times 100 \times 500 \mathrm{~mm}$ beams for flexural strength testing.

\section{Microstructural Studies}

After the crushing of the cubes, broken samples were used for microstructural tests from the surface of the specimens. To observe the changes in the samples morphology SEM images and EDS results of the selected mixes were obtained at 28 days (in secondary electron mode). The Quanta 200 FEG is a versatile high-resolution scanning electron microscope that is used for obtaining surface morphological images. The powdered samples obtained from the 28 days crushed concrete cubes were used for powdered XRD and thermogravimetric analysis. A PANalytical X'Pert Powder XRD System was used for the XRD analysis and Netzch STA 449 F3 Jupiter is used for the TGA-DTA measurements. The mineralogical phases were determined using XRD analysis while TGA is used to investigate the evaluation of mineralogical phases with temperature.

Results and discussions

\section{Workability}

The slump values, characterizing the workability, of concrete samples are shown in Figure 3. As illustrated, the slump results of fresh concrete were in the range 90 to $0 \mathrm{~mm}$. The reference $\mathrm{L} 0$ mix was found to be more workable than the laterized mixes. The incorporation of laterite caused $16.67 \%$ decrease in the workability. It is also observed that there is a further decrease in the workability with the increase in the percentage of laterite added as fine aggregate in concrete. The zero slump is attained for concrete mixes with a laterite content of $100 \%$. The usage of finer aggregates increases the surface area, thereby increasing the water demand. Thus, the low workability of the laterized samples is apparently caused by the high water absorption rate of lateritic fine aggregate compared to the natural sand. Similar findings have been reported by Gowdaa, Rajasekaran, \& Yaragal, (2018).

Figure 3. Variation in slump. Source: Self-Elaboration.

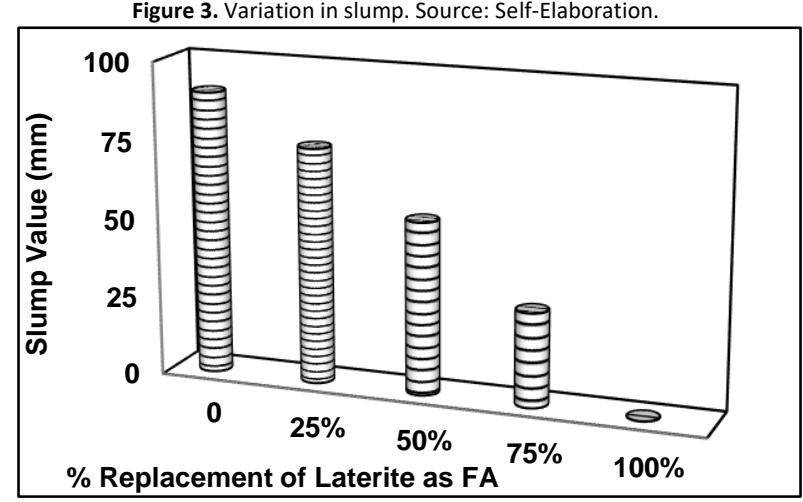

\section{Compressive Strength}

Figure 4 shows the compressive strength of the 7-and 28-day-curing concrete mixtures, consisting of $0 \%, 25 \%, 50 \%$, $75 \%$, and $100 \%$ of the fine laterite aggregate. Among all the mixes, L25 (containing $25 \%$ laterite) yielded the maximum compressive strength which represented an approximately $12 \%$ strength gain over the modified mixes without laterite, but the compressive strength decreased as the laterite content increased beyond $25 \%$. This is because of the rough surface texture of M-sand and laterite which increases the compressive strength of concrete. Gambhir (2006) reported the same phenomenon that the rough, porous texture of aggregates can increase the aggregate-cement bond by $75 \%$, which may increase the compressive up to $20 \%$. On the other hand, the reason behind the decrease in compressive strength, by the addition of laterite, is due to the presence of high clay content in laterite. For greater content of laterite (more than 50\%), the workability of the concrete is affected, and the compactness of the samples could be also affected. It is also worth noting that the strength increases with increase in the curing days and the highest increase in strength between 7 and 28 days was $55.13 \%$ for mixes with $25 \%$ laterite replacement. It is based on the fact that the curing age improves the rate of hydration which in turn enhances the compressive strength. 
Figure 4. Compressive strength. Source: Self-Elaboration.

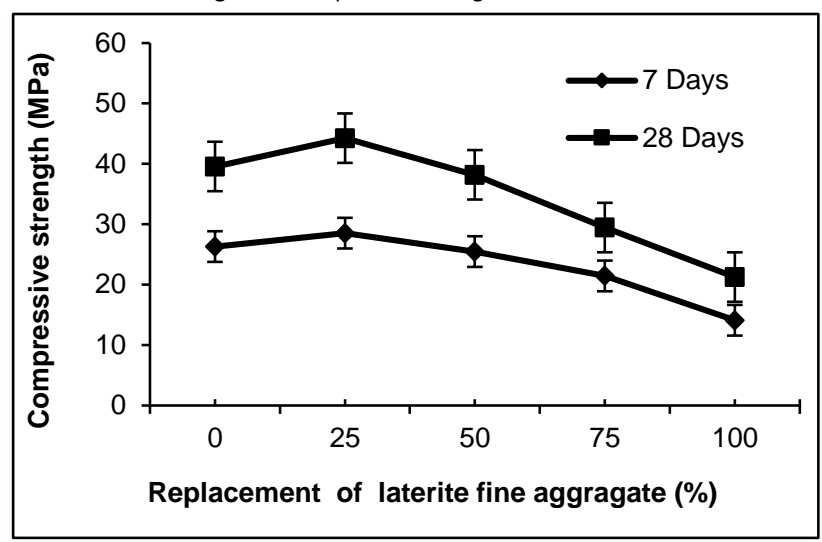

\section{Split-tensile and Flexural Strength}

As it is difficult to ascertain the tensile strength of concrete by direct tension tests, it is measured by split-tensile and flexural strength. Figure 5 shows the split-tensile and flexural strength developed by the concrete mixes. Similar to the results obtained for the compressive strength, split-tensile and flexural strength values are also increased with curing time. Just as observed, the L25 mix (containing 25\% laterite) yielded higher values. An approximate strength gain of $11.14 \%$ and $12.83 \%$ related to control concrete is attained for split-tensile and flexural strength tests respectively. The strength values increased up to $50 \%$ replacement of laterite and started to decrease beyond $50 \%$. The main reason for higher splitting tensile strength of concrete made with laterite is the decrease in porosity and distribution of pores. Because of their better aggregate-paste bonding, the crushed laterite and M-sand aggregates have more influence on the flexural strength than the compressive strength and this is the reason for considerably higher flexural strength.

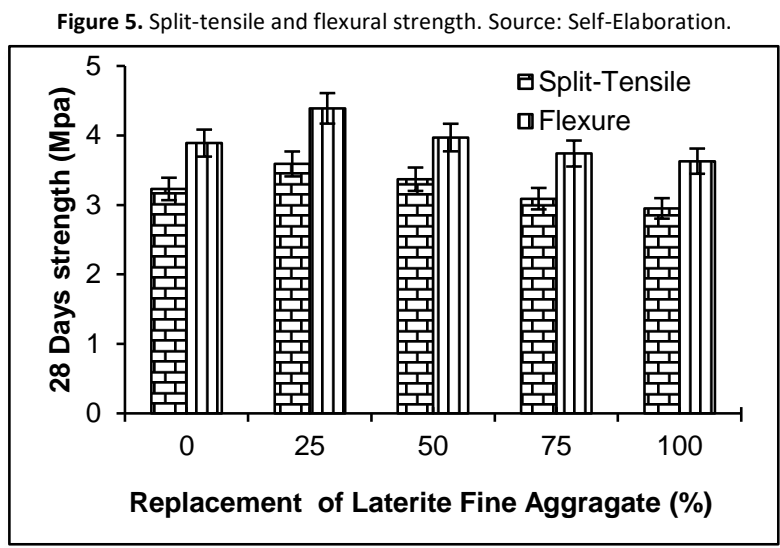

\section{Microstructural Analysis}

Two mixes, comprising the reference (LO) and optimum mix (L25) were selected for further evaluation based on their better strength gain than other samples at 28 days.

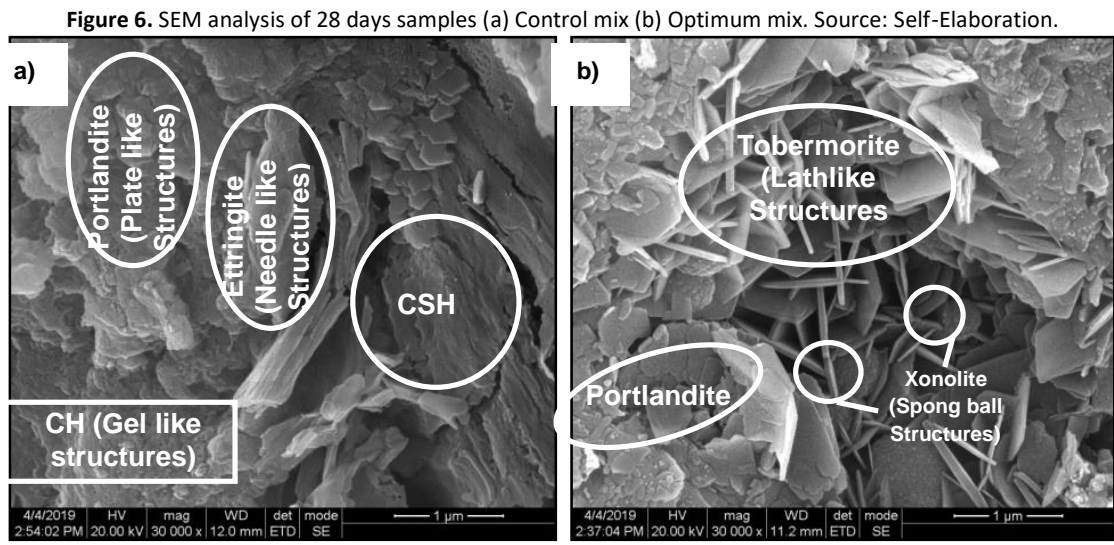


SEM Analysis. Figure 6 presents the SEM analysis of M30 grade control and optimum mixes. After 28 days, only the $\mathrm{CH}$ and CSH structures are identified in the control mix (Figure 6a). L0 mix develops hexagonal shaped and needle-shaped crystals which represent the characteristics of portlandite and ettringite respectively. The presence of ettringite is related to AFt phases where $\mathrm{F}$ indicating the possible substitution of iron for aluminum in the structure. In the same manner, the presence of portlandite is related to AFm phases where the aluminium in the structure is substituted by iron, hydroxide, and carbonate. Scrivener (1989) reported that these AFt and AFm phases will give the morphology to the hydrated crystals.

In Figure $6 \mathrm{~b}$, the formation of lathlike tobermorite crystals and sponge ball structures called xonotlite in addition to $\mathrm{CH}$ and CSH gel structures are identified. The tricalcium silicate and sometimes dicalcium silicate forms the calcium silicate hydrate complex is called tobermorite gel, which will give more strength and thermal resistance to the concrete (Sugama, Kukacka, \& Horn, 1981) and also the formation of xonolite mineral leads to the production of healthy C-S-H gel is also one of the reasons for the higher compressive strength than the control mix (Hiremath, \& Yaragal, 2017).

EDS analysis. The results of the EDS analysis conducted for the control and optimum are shown in Figure 7. On noticing the results from the EDS analysis, it can be seen vividly that Calcium ( $\mathrm{Ca}$ ) becomes the most dominant element throughout all the mixes, and $\mathrm{Si}, \mathrm{Al}, \mathrm{O}$, and $\mathrm{Fe}$ are the other elements that are identified. These presences of various elements are the characteristic of $\mathrm{CSH}, \mathrm{CH}$, and either of ettringite (AFt) or AFm (calcium mono sulfoaluminate hydrated) hydration products. Due to the high silica content in $\mathrm{M}$ - sand, the presence of the amount of silica (Si) is on a higher side in the reference samples.

Figure 7. EDS analysis of 28 days samples (a) Control mix (b) Optimum mix. Source: Self-Elaboration.

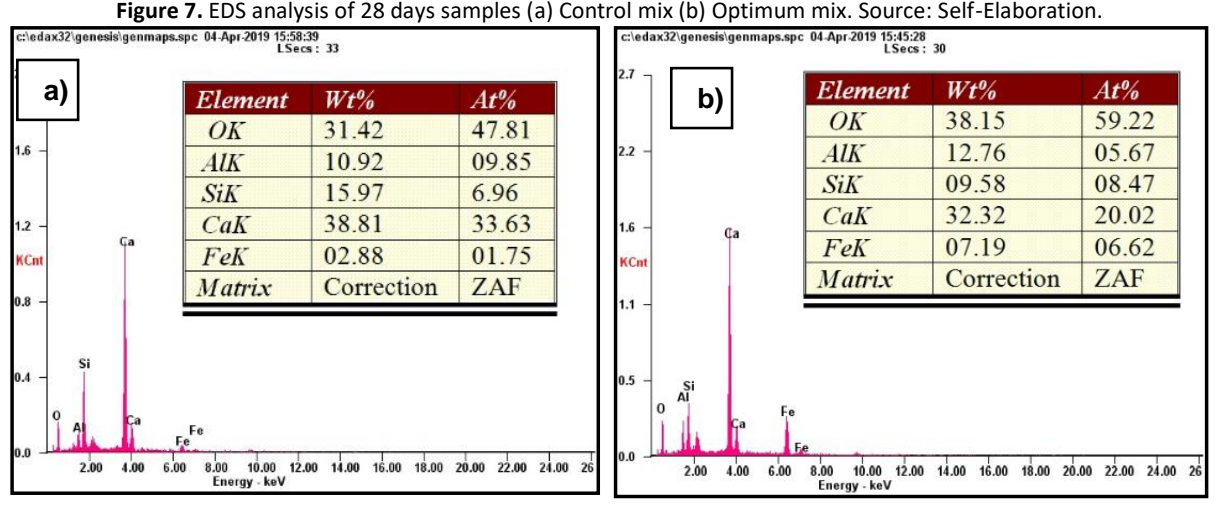

XRD Analysis. The intrinsic characteristics and the products formed during the hydration reaction of the control and optimum mixes were evaluated using XRD analysis. The diffraction angle $2 \theta$ used for XRD investigations are ranged between $5^{\circ}$ to $90^{\circ}$.

The XRD analysis of the control (LO) and optimum (L25) mixes are presented in Figure 8. In the reference mix, the crystalline phases such as quartz, portlandite, ettringite, calcium silicate, and ferrite are identified. There were relatively high-intensity peaks for calcium silicate hydrate and quartz in reference mix. However, in addition to that, the optimum (L25) mix possessed tobermorite and xonolite. The intense signals at $14.2^{\circ}(2 \theta), 18.5^{\circ}(2 \theta)$ and $28.7^{\circ}(2 \theta)$ confirm the presence of tobermorite and the XRD analysis also shows xonotlite at $43.2^{\circ}(2 \theta)$ and $50.0^{\circ}(2 \theta)$. Similar findings are reported by Hartmann, Schulenberg, \& Buhl, (2015). The peaks of calcium silicate, portlandite, and ettringite were somewhat higher in the control mix than in the $\mathrm{L} 25 \mathrm{mix}$. But there were no traces of tobermorite and xonotlite in the control mix. Thus, the XRD analysis of the optimum mix (L25) indicated that it has additional peaks of tobermorite and xonotlite compared with the reference mix (LO), which was certainly due to the adequate hydration resulted in secondary CSH gel formation.

\section{Thermogravimetric Analysis}

The hydrated phases such as dehydration, dehydroxylation, and decarbonation can be determined with a high degree of accuracy by thermogravimetry analysis (TGA and DTA). The weight loss associated with temperature changes is evaluated by the TGA curve, whereas the DTA curve shows the percentage change in the weight of the sample for $1^{\circ} \mathrm{C}$. 
Figure 8. XRD pattern of concrete samples. Source: Self-Elaboration.

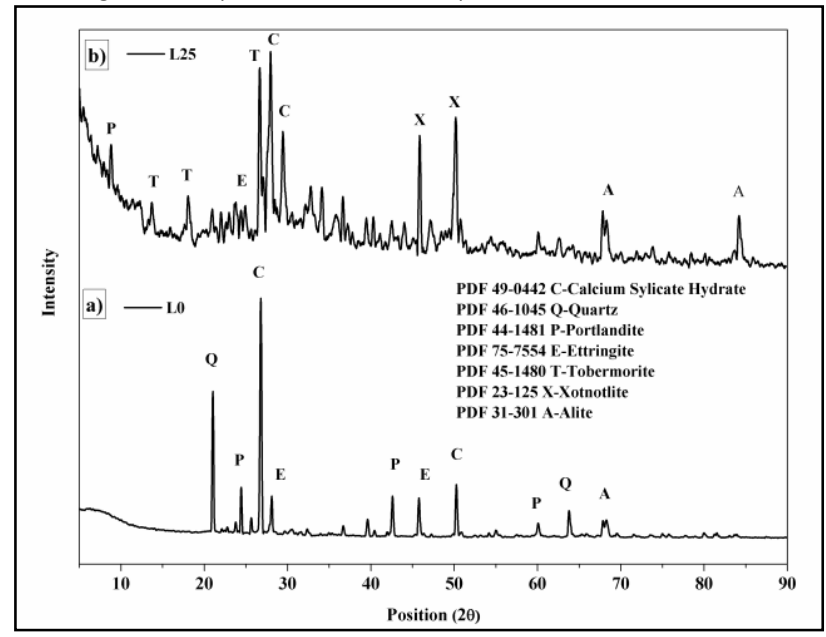

Figure 9 represents the thermal analysis of the control and optimum mix. The TGA curves of control (LO) and optimum (L25) shows that the decomposition happened at $658.69{ }^{\circ} \mathrm{C}$ and $667.26{ }^{\circ} \mathrm{C}$, and the weight losses obtained at corresponding decomposition temperature are $18.46 \%$ and $14.59 \%$ respectively. Thus, the stability of the optimum mix is higher than the reference mix. In the DTA curve of Figure 9a, there were two endothermic peaks at $53.26{ }^{\circ} \mathrm{C}$ and $630.17{ }^{\circ} \mathrm{C}$, whereas in Figure $9 \mathrm{~b}$, there were three endothermic peaks occurred at $55.93{ }^{\circ} \mathrm{C}, 286.35{ }^{\circ} \mathrm{C}$ and $648.68{ }^{\circ} \mathrm{C}$. The first peak occurred approximately at $55^{\circ} \mathrm{C}$ in both mixes represented the loss of free or bound water. Shaw, Clark, \& Henderson, (2000) reported that whether natural or synthetic tobermorite generally changes to xonotlite at about $250^{\circ} \mathrm{C}$. Thus, the additional exothermic peak at $286.3^{\circ} \mathrm{C}$ indicated that recrystallization into xonotlite occurred in Figure $9 \mathrm{~b}$. However, this study aimed at the identification of hydration phenomenon, which is responsible for the strength gain in the mixes. Borges et al. (2010) suggested the following equation to calculate the total amount of calcium hydroxide, which helps to define the hydration process. The influence of calcium hydroxide is responsible for the formation of $\mathrm{CSH}$ gels while the calcium carbonate is responsible for early strength of concrete properties Therefore, the percentage $\mathrm{CH}$ dehydroxylation for the control concrete and L25 sample were computed as $3.75 \%$ and $3.15 \%$ respectively using Equation (1). Awoyera et al. (2018) suggested that the mixes with a lower percentage of dehydroxylation value lead to the rapid development of CSH gels. This was the reason behind the higher strength development in the optimum (L25) mix (Meddah, et al. 2020).

$$
\mathrm{Ca}(\mathrm{OH})_{2}=\% \text { decarboxylation }=\frac{74}{18} A+\frac{74}{44} B
$$

Where:

$A=$ area under the DTA curve that corresponds to the total mass lost due to the dehydroxylation of $\mathrm{CH}$. $\mathrm{B}=$ area under the DTA that corresponds to the total mass lost due to the decarbonation reaction.

Figure 9. Thermogravimetric analysis of concrete samples. Source: Self-Elaboration.
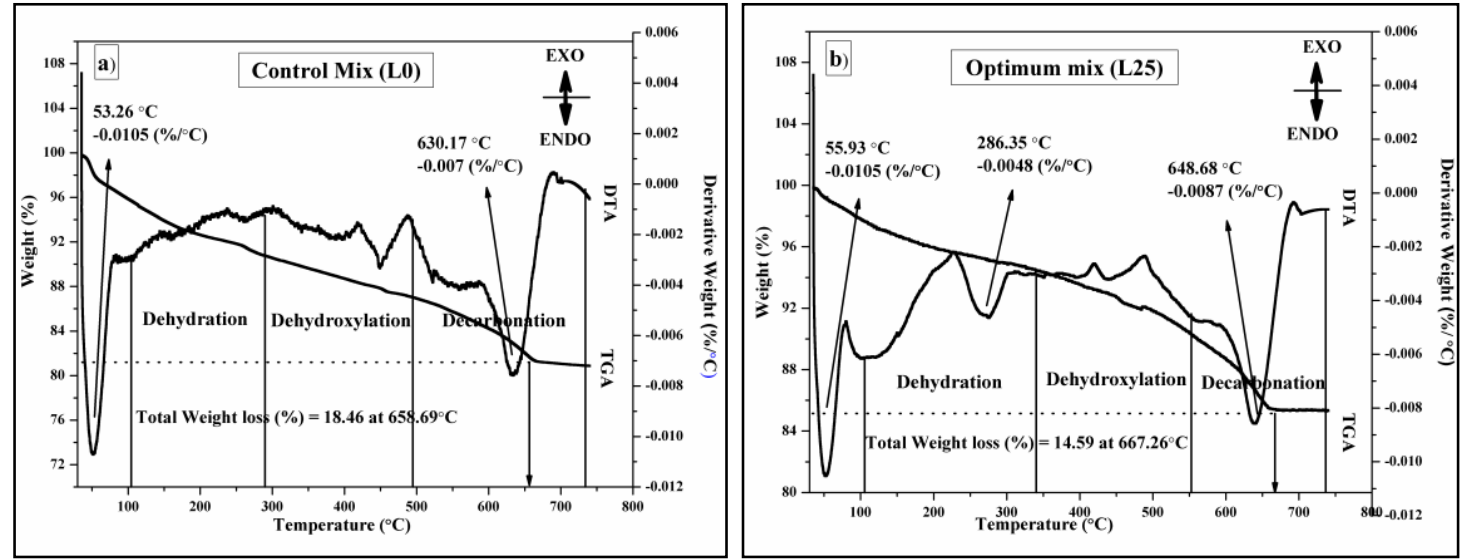
The effects of laterite incorporation on strength performance, microstructural characteristics, and phase change were explored. The following are the key findings of this study.

- Observations on fresh properties of concrete show that the incorporation of laterite in fine aggregates decreases the workability of concrete and this is due to the high water absorption rate of lateritic sand compared to $\mathrm{M}$-sand.

- Investigations of mechanical properties of concrete show that the replacement of M- Sand by $25 \%$ laterite resulted in a $12 \%$ increase of compressive strength and a strength gain of $11.14 \%$ and $12.83 \%$ related to control concrete is attained for split-tensile and flexural strength test respectively. For greater content of laterite, there is a reduction in compressive strength of concretes due to the presence of high clay content in laterite and poor workability.

- SEM and EDS analysis help to interpret the morphology and chemical composition of hydration products. The formation of lathlike tobermorite crystals and sponge ball structures called xonotlite identified is the reason for the increase in the strength of the L25 sample than the control mix (LO). The higher amount of oxygen (O), calcium (Ca), and silica (Si) in the L25 mix is also the reason for variation in strength.

- XRD analysis of the selected samples revealed that the reference concrete does not possess tobermorite and xonotlite peaks, which clearly indicated that the presence of these peaks in the optimum concrete composition is due to the addition of laterite. The evaluation of hydration products at different temperatures can be inferred with the thermogravimetry analysis.

Acknowledgment

This research was funded by the Anna centenary research fellowship scheme Grant No: CFR/ACRF2018/AR1/2 of Anna University, India, which is gratefully acknowledged.

References

Adepegba, D. (1975). A comparative study of normal concrete with concrete which contained laterite instead of sand. Building Science, 10(2), 135141. https://doi.org/10.1016/0007-3628(75)90029-8

Alawode, O., \& Idowu, O. (2011). Effects of Water-Cement Ratios on the Compressive Strength and Workability of Concrete and Lateritic Concrete Mixes. The Pacific Journal of Science and Technology, 12(2), 99-105.

Awoyera, P. O., Akinmusuru, J. O., Dawson, A. R., Ndambuki, J. M., \& Thom, N. H. (2018). Microstructural characteristics, porosity and strength development in ceramic-laterized concrete. Cement and Concrete Composites, 86 , $224-237$. https://doi.org/10.1016/j.cemconcomp.2017.11.017

Awoyera, P. O., Dawson, A. R., Thom, N. H., \& Akinmusuru, J. O. (2017). Suitability of mortars produced using laterite and ceramic wastes: Mechanical and microscale analysis. Construction and Building Materials, 148, 195-203. https://doi.org/10.1016/j.conbuildmat.2017.05.031

Balogun, L. A., \& Adepegba, D. (1982). Effect of varying sand content in laterized concrete. International Journal of Cement Composites and Lightweight Concrete. 4(4), 235-240. https://doi.org/10.1016/0262-5075(82)90027-6

Borges, P. H. R., Costa, J. O., Milestone, N. B., Lynsdale, C. J., \& Streatfield, R. E. (2010). Carbonation of CH and C-S-H in composite cement pastes containing high amounts of BFS. Cement and Concrete Research, 40(2), 284-292. https://doi.org/10.1016/j.cemconres.2009.10.020

Gambhir M. L. (2013). Concrete Technology. New Delhi: McGraw Hill Education.

Gowda, S. N. B., Rajasekaran, C., \& Yaragal, S. C. (2018). Significance of processing laterite on strength characteristics of laterized concrete. IOP Conference Series: Materials Science and Engineering, 431(8). https://doi.org/10.1088/1757-899X/431/8/082003

Hartmann, A., Schulenberg, D., \& Buhl, J.-C. (2015). Investigation of the Transition Reaction of Tobermorite to Xonotlite under Influence of Additives. Advances in Chemical Engineering and Science, 05(02), 197-214. https://doi.org/10.4236/aces.2015.52022

Hiremath, P. N., \& Yaragal, S. C. (2017). Effect of different curing regimes and durations on early strength development of reactive powder concrete. Construction and Building Materials, 154(October), 72-87. https://doi.org/10.1016/j.conbuildmat.2017.07.181

IS 10262. (2019). Indian Standard for Concrete Mix Proportioning - Guidelines. Bureau of Indian Standards.

IS 12269. (2013). Indian Standard Ordinary Portland Cement, 53 Grade. Bureau of Indian Standards.

IS 2386-3. (2016). Indian Standard Method of Test for aggregate for concrete- specific gravity, density, voids, absorption and bulking. Bureau of Indian Standards.

IS 2386-4. (2016). Indian Standard Methods of test for aggregates for concrete, Mechanical properties. Bureau of Indian Standards.

IS 3812-2. (2013). Indian Standard Pulverized fuel ash-Specification Part-2. Bureau of Indian Standards. 
IS 7320. (2018). Specification for concrete slump test apparatus. Bureau of Indian Standards.

Lasisi, F., Ajayi, E.O., \& Osunade, J. A. (1984). Technical notes: Strength characteristics of laterite - cement mortars. International Journal of Cement Composites, 6(3), 201-203.

Lasisi, F., \& Osunade, J. A. (1985). Factors affecting the strength and creep properties of laterized concrete. Building and Environment, 20(2), 133138. https://doi.org/10.1016/0360-1323(85)90008-3

Lasisi, F., Osunade, J. A., \& Adewale, A. O. (1990). Short-term studies on the durability of laterized concrete and laterite-cement mortars. Building and Environment, 25(1), 77-83. https://doi.org/10.1016/0360-1323(90)90044-R

Meddah, M. S., Praveenkumar, T. R., Vijayalakshmi, M. M., Manigandan, S., Arunachalam, R. (2020). Mechanical and microstructural characterization of rice husk ash and $\mathrm{Al}_{2} \mathrm{O}_{3}$ nanoparticles modified cement concrete. Construction and Building Materials, 255 , 119358. https://doi.org/10.1016/j.conbuildmat.2020.119358

Mathew, G., \& Paul, M. M. (2012). Mix design methodology for laterized self compacting concrete and its behaviour at elevated temperature. Construction and Building Materials, 36, 104-109. https://doi.org/10.1016/j.conbuildmat.2012.04.057

Nandhini, K., Ponmalar, V. (2018). Microstructural behavior and flowing ability of self-compacting concrete using micro- and nano- silica. Micro and Nano Letters, 13(8), 1213-1218. http://dx.doi.org/10.1049/mnl.2018.0105

Olawuyi, B. J., \& Olusola, K. O. (2010). Compressive Strength of Volcanic Ash/Ordinary Portland Cement Laterized Concrete. Civil Engineering Dimension, 12(1), 23-28. https://doi.org/10.9744/ced.12.1.23-28

Rajan, L., \& Joy, A. (2016). Experimental Investigation on Strength Parameters of Laterised Concrete after Adding Silica Fume. International Journal of Science and Research (IJSR), 5(6), 1579-1583. https://doi.org/10.21275/v5i6.nov164463

Sateshkumar, S. K., Awoyera, P. O., Kandasamy, T., Nagaraj, S., Murugesan, P., \& Ponnusamy, B. (2018). Impact resistance of high strength chopped basalt fibre-reinforced concrete. Revista de la Construccion, 240-248. https://doi.org/10.7764/RDLC.17.2.240

Scrivener, K. (1989). The Microstructure of Concrete. Materials Science of Concrete I, 127-161. https://doi.org/10.1016/0008-8846(95)00036-C

Shaw, S., Clark, S. M., \& Henderson, C. M. B. (2000). Hydrothermal formation of the calcium silicate hydrates, tobermorite $\left(\mathrm{Ca}_{5} \mathrm{Si}_{6} \mathrm{O}_{16}(\mathrm{OH})_{2} \cdot 4 \mathrm{H}_{2} \mathrm{O}\right)$ and xonotlite $\left(\mathrm{Ca}_{6} \mathrm{Si}_{6} \mathrm{O}_{17}(\mathrm{OH})_{2}\right)$ : An in situ synchrotron study. Chemical Geology, 167(1-2), 129-140. https://doi.org/10.1016/S0009-2541(99)002053

Sugama, T., Kukacka, L. E., \& Horn, W. (1981). Effects of tobermorite and calcium silicate hydrate (I) crystals formed within polymer concretes. Journal of Materials Science, 16(2), 345-354. https://doi.org/10.1007/BF00738623

Udoeyo, F. F., Iron, U. H., \& Odim, O. O. (2006). Strength performance of laterized concrete. Construction and Building Materials, $20(10), 1057-1062$. https://doi.org/10.1016/j.conbuildmat.2005.03.002

Udoeyo, F. F., Brooks, R., Utam, C., Udo-inyang, P., \& Ukpong, E. C. (2010). Effect of non-standard curing methods on the compressive strength of laterized concrete. ARPN Journal of Engineering and Applied Sciences, 5(2), 6-20.

Ukpata, J. O., \& Ephraim, M. E. (2012). Flexural and tensile strength properties of concrete using lateritic sand and quarry dust as fine aggregate. ARPN Journal of Engineering and Applied Sciences, 7(3), 324-331. 